\title{
Vitamin D status in the first-trimester: effects of Vitamin D deficiency on pregnancy outcomes.
}

\author{
Seda Ates ${ }^{1}$, Osman Sevket ${ }^{1}$, Pinar Ozcan ${ }^{1}$, Fulya Ozkal ${ }^{1}$, Mehmet Onur Kaya ${ }^{2}$, Banu Dane ${ }^{1}$
}

1 Bezmialem Vakif University, Faculty of Medicine, Department of Obstetrics and Gynecology, Istanbul, Turkey 2 Bezmialem Vakif University, Faculty of Medicine, Department of Biostatistics and Medical Informatics, Istanbul, Turkey

\begin{abstract}
Objective: To assess serum levels of 25-hydroxyvitamin $\mathrm{D}[25(\mathrm{OH}) \mathrm{D}]$ in the first trimester and to determine the factors affecting deficiency levels and its association with pregnancy outcomes.

Methods: Serum 25(OH)D concentrations were measured at 11-14 weeks' gestation in 229 singleton pregnancies using liquid chromatography-tandem mass spectrometry.

Results: The median serum $25(\mathrm{OH}) \mathrm{D}$ concentration was $10.8 \mathrm{ng} / \mathrm{mL}$ and $45.9 \%$ of women had severe vitamin D deficiency with concentrations of $<10 \mathrm{ng} / \mathrm{mL}$. Logistic regression analysis revealed that covered dressing style, lack of multivitamin intake, season of blood sampling (November-April) were factors associated with $25(\mathrm{OH}) \mathrm{D}$ deficiency. There was a negative correlation between 25(OH)D levels and gestational age at sampling. Low 25(OH)D levels were not associated with adverse pregnancy outcomes. Higher rate of cesarean section (CS) was noted in women with $25(\mathrm{OH}) \mathrm{D} \geq 10 \mathrm{ng} / \mathrm{mL}$ compared to those with $25(\mathrm{OH}) \mathrm{D}<10 \mathrm{mg} / \mathrm{ml}(\mathrm{p}=0.01)$.

Conclusion: A high prevalence of vitamin D deficiency was observed in early pregnancy which was related to dress code, use of multi-vitamins and season at sampling. Low 25(OH)D levels were not related with adverse pregnancy outcomes. Women with severe vitamin $\mathrm{D}$ deficiency were more likely to deliver vaginally.

Keywords: 25-hydroxyvitamin D; pregnancy outcome; vitamin D deficiency

DOI: http://dx.doi.org/10.4314/ahs.v16i1.5

Cite as: Ates S, Sevket O, Ozcan P, O₹zkal F, Kaya MO, Dane B. Vitamin D status in the first-trimester: effects of Vitamin D deficiency on pregnancy outcomes. Afri Health Sci. 2016;16(1): 36-43. http:// dx.doi.org/10.4314/abs.v16i1.5
\end{abstract}

\section{Introduction}

The prevalence of vitamin $\mathrm{D}$ deficiency has increased and continues to be a major public health problem in many countries ${ }^{1}$. High prevalence of vitamin D deficiency has been observed among pregnant women even in sun-rich areas. The main source of vitamin D is endogenous synthesis in the skin following exposure to sunlight, though a small percentage comes from dietary sources and supplement intake ${ }^{3}$. Vitamin D level is influenced by many factors such as skin pigmentation, use

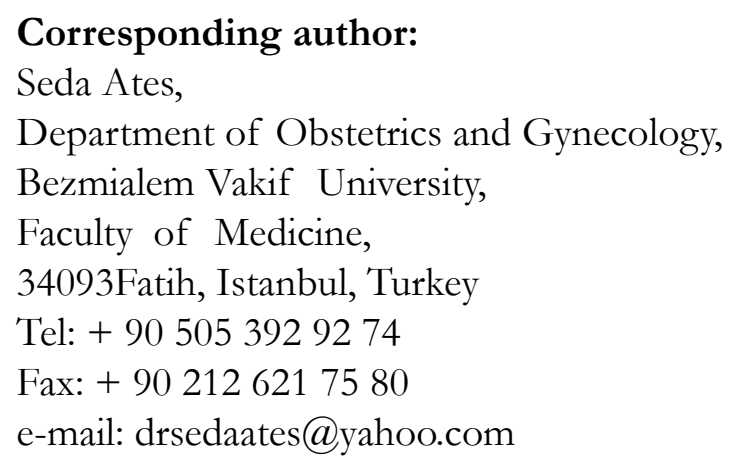

of sunscreen, ethnicity, dress code,, geographic latitude, seasonal variation and use of prenatal vitamins ${ }^{4,5,6,7}$.

Several studies reported the relationship between maternal vitamin $\mathrm{D}$ deficiency and adverse maternal and fetal outcomes including gestational diabetes, preeclampsia, preterm labor, low birth weight, and ceasarean section $^{8,9}$.

Determination of vitamin D status in the first trimester provides an opportunity for early detection and prophylaxis of vitamin D deficiency that may help to reduce adverse pregnancy outcomes. The aim of this study was to assess the first trimester serum levels of 25-hydroxyvitamin $\mathrm{D}[25(\mathrm{OH}) \mathrm{D}]$ and the factors affecting the low levels in pregnant women. The association between vitamin D status and obstetric-neonatal outcomes were also evaluated.

\section{Materials and methods}

A total of 229 consecutive pregnant women who attended for their first antenatal visit (11-14 weeks of preg- 
nancy) at the outpatient clinic of Obstetrics and Gynecology, Bezmialem Vakif University, Istanbul, Turkey between December 2012 and July 2014 were studied. This study was approved by the Ethics Committee of our hospital. All participants were informed about the purpose of the study and requested to participate after giving written consent. They were asked to complete a questionnaire that included the characteristics of their pregnancy and information about the factors associated with vitamin D status. Non-fasting blood samples were taken and analyzed for $25(\mathrm{OH}) \mathrm{D}$ levels. The pregnancies were followed up until the end of their last trimester and the pregnancy outcomes were recorded in our database. At the end of the study, the data of pregnancy and neonatal outcomes were obtained from medical records and reviewed cautiously.

Women with a history of thyroid, parathyroid or adrenal disease, hepatic or renal failure, metabolic bone diseases and those taking medications that might affect vitamin $\mathrm{D}$ metabolism were excluded from the study. Multiple pregnancies were also excluded. None of the women in this study had previously received vitamin D supplementation.

Data on maternal characteristics included age, parity, blood pressure, pre-pregnancy weight, height, date of last menstrual period, smoking status (yes or no), education level, gestational age at blood sampling, type of clothing, consumption of milk and dairy products, use of multivitamin supplements, sunlight exposure (between 10 AM and 3 PM) and season of blood collection. Covered dressing style was defined as wearing dresses which cover body completely excluding hands and face whereas uncovered dressing style was wearing dresses exposing body to more sun light in a permissive manner. Consuming dairy products of at least $200 \mathrm{~mL}$ of milk or other milkproducts including cheese, butter, yoghurt 4-7 days/week was regarded as 'sufficient' milk consumption, whereas intake of dairy products three times a week or less was defined as 'insufficient' consumption ${ }^{10}$. The season for blood collection was dichotomized into winter (November-April) and summer (May-October).

Obstetric and neonatal data including gestational age, mode of delivery, and frequency of pregnancy-related complications, birth weight, Apgar scores, neonatal gender and presence of congenital anomalies were also recorded. The gestational age at delivery was determined by menstrual dating, while the ultrasound esti- mates of gestational age were used in women that had missed or uncertain dates. The estimated date of delivery was determined by last menstrual period or by early ultrasound. Gestational hypertension was defined as a blood pressure of $140 / 90 \mathrm{mmHg}$ or higher that develops after 20 weeks of gestation. Proteinuria was defined as a urine dipstick test $\geq 2+$, or more than $300 \mathrm{mg}$ of protein in a 24-hour urine collection. Pre-eclampsia was defined as gestational hypertension with proteinuria ${ }^{11}$. The diagnosis of gestational diabetes mellitus (GDM) was performed using a 2-step approach which involves an initial screening by measuring the plasma glucose 1 hour after a 50-g oral glucose load. If the plasma glucose level was $135 \mathrm{mg} / \mathrm{dL}$ or higher, it was followed by a 3-hour 100-g oral glucose tolerance test to establish the diagnosis of $\mathrm{GDM}^{12}$. We defined preterm delivery as live births between 21 weeks and 36 weeks 6 days of gestation ${ }^{13}$. Stillbirth was defined as fetal death occurring after 20 weeks of gestation ${ }^{14}$. Infants were considered to be small-for gestational age (SGA) if the birth weight was less than the 10 th percentile for their gestational age $e^{15}$.

Measurement of $25(\mathrm{OH}) \mathrm{D} 3$ and $25(\mathrm{OH}) \mathrm{D}_{2}$ in human serum was made by using liquid chromatography-tandem mass spectrometry (LC-MS/MS) with an Agilent 1200 Infinity liquid chromatography (Agilent Technologies) coupled to an Agilent Technologies 6460 LC-MS/ MS. The summation of serum $25(\mathrm{OH}) \mathrm{D}_{2}$ and $25(\mathrm{OH})$ $\mathrm{D}_{3}$ was used to reflect total serum $25(\mathrm{OH}) \mathrm{D}$ concentrations. The inter-assay and intra-assay coefficients of variation of total serum $25(\mathrm{OH}) \mathrm{D}$ level were $6.84 \%$ and $2.21 \%$, respectively. The lower and upper limits of detection were 4.0 and $200 \mathrm{ng} / \mathrm{mL}$, respectively. Although there is no consensus regarding the optimal $25(\mathrm{OH}) \mathrm{D}$ level, vitamin D status was categorized into groups as serum $25(\mathrm{OH}) \mathrm{D}$ levels $<10 \mathrm{ng} / \mathrm{mL}$, between $10-19 \mathrm{ng} / \mathrm{mL}, 20-29 \mathrm{ng} / \mathrm{mL}$ and $>30 \mathrm{ng} / \mathrm{mL}$, indicating severe, moderate and mild vitamin $\mathrm{D}$ deficiency and desirable reference limit, respectively ${ }^{16}$.

Data was presented as mean \pm standard deviation (SD) and median (minimum to maximum), and as percentages for categorical variables. The presence of a normal distribution for each variable was tested by the Shapiro Wilks test. Continuous variables were compared between groups by independent samples $t$ tests for normally distributed variables and the Mann-Whitney U test for non-normally distributed variables. Pearson chi-square, Yates corrected chi-squared, and Fisher's exact tests were performed for categorical variables. 
Spearman's rho correlation coefficient was used to identify the relationship between 25(OH)D and several continuous and numeric outcome variables: gestational age at serum collection, BMI, birth weight, Apgar score, gestational age at delivery. A logistic regression model was used to determine the factors associated with low levels of vitamin D. All data was analyzed using SPSS (SPSS, Inc., Chicago, IL, USA) and $\mathrm{p}$ values $<0.05$ were considered statistically significant.

\section{Results}

A total of 286 women were invited to participate in this study. Fifty-seven of them were excluded from the analysis. Reasons for exclusion were planned to be followed-up elsewhere $(n=15)$, decline to participate $(n=5)$, lost to follow up $(n=27)$, insufficient serum available for analysis $(n=7)$, miscarriage $(n=2)$, and termination of pregnancy because of Down's syndrome $(\mathrm{n}=1)$. After exclusion of the women mentioned above, 229 women were eligible for follow-up at the end of their pregnancy.

Characteristics of the study population are shown in Table 1. The median serum $25(\mathrm{OH}) \mathrm{D}$ concentration was $13 \pm 9,4 \mathrm{ng} / \mathrm{mL}$ at 11-14 weeks of gestation, only $4.4 \%$ of the pregnancies had adequate serum $25(\mathrm{OH}) \mathrm{D}$ levels $(>30 \mathrm{ng} / \mathrm{mL})$. The prevalence of severe, moderate, and mild vitamin $\mathrm{D}$ deficiency was $45.9 \%(\mathrm{n}=105)$, $36.2 \%(n=83)$, and $13.5 \%(n=31)$, respectively.

\section{Table 1. Characteristics of the study population}

\begin{tabular}{|c|c|}
\hline Age (years) & $29.49 \pm 4.879$ \\
\hline \multicolumn{2}{|l|}{ Parity } \\
\hline Nulliparous, n (\%) & $81(35.5)$ \\
\hline Parous, $\mathrm{n}(\%)$ & $147(64.5)$ \\
\hline BMI (kg/m2) & $25.3 \pm 4.5$ \\
\hline \multicolumn{2}{|l|}{ Education, n (\%) } \\
\hline $0-5$ years & $75(35.2)$ \\
\hline $6-8$ years & $38(17.8)$ \\
\hline$\geq 9$ years & $100(46.9)$ \\
\hline Smoking, $\mathrm{n}(\%)$ & $15(6.6)$ \\
\hline Gestational age at serum collection (week) & $13.2(11-14)$ \\
\hline \multicolumn{2}{|l|}{ Season of blood sampling, $\mathrm{n}(\%)$} \\
\hline Winter (November-April) & $116(51.1)$ \\
\hline Summer (May-October) & $111(48.9)$ \\
\hline Mean systolic BP at trial entry (mmHg) & $100(80-165)$ \\
\hline Mean diastolic BP at trial entry $(\mathrm{mmHg})$ & $70(50-100)$ \\
\hline \multicolumn{2}{|l|}{ Maternal multivitamin use, $\mathrm{n}(\%)$} \\
\hline Yes & $118(63.1)$ \\
\hline No & $69(36.9)$ \\
\hline \multicolumn{2}{|l|}{ Consumption of dairy products, $\mathrm{n}(\%)$} \\
\hline Sufficient & $97(49.7)$ \\
\hline Insufficient & $98(50.3)$ \\
\hline \multicolumn{2}{|l|}{ Dressing style, n (\%) } \\
\hline Covered & $117(61.3)$ \\
\hline Uncovered & $74(38.7)$ \\
\hline \multicolumn{2}{|l|}{ Exposure to sun, $\mathrm{n}(\%)$} \\
\hline Yes & $89(46.4)$ \\
\hline No & $103(53.6)$ \\
\hline
\end{tabular}

Data are shown as mean $\pm \mathrm{SD}$, median (minimum-maximum) or $\mathrm{n}(\%)$.

BMI, body mass index; BP, blood pressure; 25(OH)D, 25-hydroxyvitamin D

Table 2 shows the baseline characteristics, and the obstetric-neonatal outcomes of the participants accord- ing to vitamin $\mathrm{D}$ status. The subjects were divided into two groups using $25(\mathrm{OH}) \mathrm{D}<10 \mathrm{ng} / \mathrm{mL}$ as a cut off 
limit to identify severe deficiency; 105 (46\%) women had $25(\mathrm{OH}) \mathrm{D}<10 \mathrm{ng} / \mathrm{mL}$ (group 1), while 124 (54\%) women had $25(\mathrm{OH}) \mathrm{D} \geq 10 \mathrm{ng} / \mathrm{mL}$ (group 2). We also compared the groups and found no significant differ- ences between the groups concerning maternal age, BMI values, parity, education level, smoking, systolic and diastolic blood pressures at the baseline study visit and gestational age at serum collection.

Table 2. Association of serum 25-hydroxyvitamin D [25(OH)D] with pregnancy outcomes

\begin{tabular}{|c|c|c|c|}
\hline \multirow{4}{*}{$\begin{array}{l}\text { Age (years) } \\
\text { Parity }^{\mathrm{b}}\end{array}$} & \multicolumn{3}{|c|}{ Serum $25 \mathrm{OH}$ concentration $(\mathrm{ng} / \mathrm{mL})$} \\
\hline & \multirow{2}{*}{$\begin{array}{l}<10 \mathrm{ng} / \mathrm{mL}(\mathrm{n}=105) \\
28.85 \pm 4.99\end{array}$} & \multirow{2}{*}{$\begin{array}{l}=10 \mathrm{ng} / \mathrm{mL}(\mathrm{n}=124) \\
30.03 \pm 4.73\end{array}$} & \multirow{2}{*}{$\begin{array}{l}\mathrm{p} \\
0.067\end{array}$} \\
\hline & & & \\
\hline & \multicolumn{3}{|c|}{ Parity $^{\mathrm{b}}$} \\
\hline Nulliparous, n (\%) & $39(37.1)$ & $42(34.1)$ & \multirow[t]{2}{*}{0.63} \\
\hline Parous, n $(\%)$ & $66(62.9)$ & $81(65.9)$ & \\
\hline $\operatorname{BMI}\left(\mathrm{kg} / \mathrm{m}^{2}\right)^{\mathrm{a}}$ & $25.60 \pm 4.8$ & $25.03 \pm 4.21$ & 0.35 \\
\hline \multicolumn{4}{|l|}{ Education, $\mathrm{n}(\%)^{\mathrm{b}}$} \\
\hline $0-5$ years & $41(42.7)$ & $34(29.1)$ & \multirow[t]{3}{*}{0.10} \\
\hline $6-8$ years & $14(14.6)$ & $24(20.5)$ & \\
\hline$=9$ years & $41(42.7)$ & $59(50.4)$ & \\
\hline Smoking, $n(\%)^{\mathrm{c}}$ & $6(5.7)$ & $9(7.4)$ & 0.81 \\
\hline Gestational age at serum collection (week) ${ }^{\mathrm{d}}$ & $13.4(11-14)$ & $13.2(11-14)$ & 0.06 \\
\hline Gestational age at delivery (week) ${ }^{d}$ & $39(34-41)$ & $39(24-41)$ & 0.56 \\
\hline \multicolumn{4}{|l|}{ Season of blood sampling, $n(\%)^{b}$} \\
\hline Winter (November-April) & $71(68.3)$ & $45(36.6)$ & \multirow[t]{2}{*}{$<0.0001$} \\
\hline Summer (May-October) & $33(31.7)$ & $78(63.4)$ & \\
\hline Mean systolic BP at trial entry $(\mathrm{mmHg})^{\mathrm{d}}$ & $100(80-165)$ & $100(80-140)$ & 0.84 \\
\hline Mean diastolic BP at trial entry $(\mathrm{mmHg})^{\mathrm{d}}$ & $70(50-95)$ & $70(50-100)$ & 0.59 \\
\hline \multicolumn{4}{|l|}{ Maternal multivitamin use, $\mathrm{n}(\%)^{\mathrm{b}}$} \\
\hline Yes & $49(53.8)$ & $69(71.9)$ & \multirow[t]{2}{*}{0.011} \\
\hline No & $42(46.2)$ & $27(28.1)$ & \\
\hline \multicolumn{4}{|l|}{ Consumption of dairy products, $\mathrm{n}(\%)^{\mathrm{b}}$} \\
\hline Sufficient & $37(39.4)$ & $60(59.4)$ & \multirow[t]{2}{*}{0.005} \\
\hline Insufficient & $57(60.6)$ & $41(40.6)$ & \\
\hline \multicolumn{4}{|l|}{ Dressing style, $n(\%)^{\mathrm{c}}$} \\
\hline Covered & $75(79.8)$ & $42(43.3)$ & \multirow[t]{2}{*}{$<0.001$} \\
\hline Uncovered & $19(20.2)$ & $55(56.7)$ & \\
\hline \multicolumn{4}{|l|}{ Exposure to sun, $\mathrm{n}(\%)^{\mathrm{b}}$} \\
\hline Yes & $42(44.7)$ & $47(48)$ & \multirow[t]{2}{*}{0.64} \\
\hline No & $52(55.3)$ & $51(52)$ & \\
\hline \multicolumn{4}{|l|}{ Mode of delivery, $\mathrm{n}(\%)^{\mathrm{c}}$} \\
\hline Vaginal delivery & $63(53.8)$ & $54(46.2)$ & \multirow[t]{2}{*}{0.018} \\
\hline Primary caesarean section & $17(32.7)$ & $35(67.3)$ & \\
\hline Gestational diabetes, $\mathrm{n}(\%)^{\mathrm{c}}$ & $10(9.5)$ & $10(8.1)$ & 0.87 \\
\hline \multicolumn{4}{|l|}{ Hypertensive states, n (\%) } \\
\hline Pre-eclampsia ${ }^{\mathrm{e}}$ & $2(1.9)$ & $2(1.6)$ & 1 \\
\hline Gestational hypertension $^{c}$ & $5(4.8)$ & $6(4.8)$ & 1 \\
\hline Preterm birth, $n(\%)^{\mathrm{c}}$ & $5(4.8)$ & $7(5.6)$ & 0.99 \\
\hline Small for gestational age, $\mathrm{n}(\%)^{\mathrm{c}}$ & $7(6.7)$ & $6(4.8)$ & 0.75 \\
\hline Intrauterine fetal death, $n(\%)^{e}$ & $1(1)$ & $1(1)$ & 1 \\
\hline Congenital malformation, $\mathrm{n}(\%)^{\mathrm{c}}$ & $2(1.9)$ & $1(0.8)$ & 0.88 \\
\hline Birth weight $(g)^{a}$ & $3245 \pm 496$ & $3272 \pm 440$ & 0.66 \\
\hline \multicolumn{4}{|l|}{ Apgar score ${ }^{\mathrm{d}}$} \\
\hline $1 \mathrm{~min}$ & $8(6-9)$ & $8(6-9)$ & 0.36 \\
\hline $5 \mathrm{~min}$ & $9(8-10)$ & $9(8-10)$ & 0.22 \\
\hline Infant gender (female), $\mathrm{n}(\%)^{\mathrm{b}}$ & $51(51)$ & $50(44.6)$ & 0.35 \\
\hline
\end{tabular}

Data are shown as mean $\pm \mathrm{SD}$, median (minimum-maximum) or $\mathrm{n} \quad(\%) .{ }^{\mathrm{a}} \mathrm{t}$-test; ${ }^{\mathrm{b}}$ Pearson chi-squared test; ${ }^{\mathrm{c}}$ Yatescorrected chi squared test; ${ }^{d}$ Mann-Whitney U test; ${ }^{e}$ Fisher's exact test

BMI, body mass index; BP, blood pressure 
Vitamin D status was found to be significantly higher in women who used multi-vitamins during pregnancy and who had higher consumption of dairy products compared to women who did not use multi-vitamins and had lower consumption of dairy products respectively. Pregnant women whose blood samples were drawn in summer months had significantly higher levels of $25(\mathrm{OH}) \mathrm{D}$ than those examined in winter months. Women with covered dressing style had significant- ly lower levels of $25(\mathrm{OH}) \mathrm{D}$ than that of women who were dressed in uncovered style. Binary logistic regression analysis determined that covered dressing style, absence of receiving multivitamin supplements, season of blood sampling (November-April) were factors related to severe vitamin $\mathrm{D}$ deficiency, while other variables such as BMI, parity, smoking, consumption of dairy products and sun exposure were not significantly related to $25(\mathrm{OH}) \mathrm{D}$ levels (Table 3$)$.

Table 3. Logistic regression analysis of factors associated with serum 25(OH)D status

\begin{tabular}{llll}
\hline $\begin{array}{l}\text { Variables } \\
\text { Dressing style }\end{array}$ & OR $^{\mathrm{a}}$ & $95 \% \mathrm{CI}$ & p-value \\
$\quad$ Covered & Ref & & \\
$\quad$ Uncovered & 5.1 & $2.26-11$ & \\
Maternal multivitamin use & & & \\
$\quad$ No & Ref & $1.28-5.66$ & 0.009 \\
$\quad$ Yes & 2.69 & & \\
$\begin{array}{l}\text { Season of blood sampling } \\
\text { Winter }\end{array}$ & Ref & 5 & $<0.0001$ \\
$\quad$ Summer & 5 & $2.32-10.7$ & \\
\hline
\end{tabular}

OR, odds ratio; CI, confidence interval; Ref, reference category.

There were no differences in the frequency of adverse obstetric and neonatal outcomes in women with $25(\mathrm{OH})$ D concentrations $<10 \mathrm{ng} / \mathrm{mL}$ compared to those with concentrations $\geq 10 \mathrm{ng} / \mathrm{mL}$ (Table 2 ).

The mode of delivery was vaginal in 118 cases (51.5\%), and caesarean delivery in 111 cases (48.5\%) of which 52 $(30.7 \%)$ had primary caesareans. The current analysis was limited to women who delivered vaginally and who delivered by primary caesarean. A significantly higher primary caesarean section rate was noted in women with $25(\mathrm{OH}) \mathrm{D}$ concentration $\geq 10 \mathrm{ng} / \mathrm{mL}$ compared to those with $25(\mathrm{OH}) \mathrm{D}<10(67.3 \%$ vs $32.7 \%, \mathrm{p}=0.018)$.

There were no significant correlations between the $25(\mathrm{OH}) \mathrm{D}$ levels and numerical outcome variables including gestational age at delivery, birth weight and Apgar scores while there was a weak negative correlation between $25(\mathrm{OH}) \mathrm{D}$ levels and gestational age at sampling (Spearman's rho $=-0.161, \mathrm{p}=0.015)$. The correlation analysis revealed that $25(\mathrm{OH}) \mathrm{D}$ levels at 11 th week of gestation was higher than those at 14th week of gestation.

\section{Discussion}

The findings of this study indicate that the higher prevelance of severe vitamin D deficiency (45.8\%) in preg- nant women is likely to be a result of less exposure to sunlight due to their dress code and lack of multivitamin usage. Higher rates of severe vitamin D deficiency were previously reported in the literature from Turkey ${ }^{10,17}$. Those prior studies have shown that covered dress style may be an important factor affecting the prevalence of vitamin $\mathrm{D}$ deficiency in Muslim populations due to the religious and cultural reasons ${ }^{10,18 .}$

The prevalence of low vitamin $\mathrm{D}$ levels was greater in cases which were sampled in winter, in women who had limited access to sunlight, those living in countries at higher latitudes and those with higher skin pigmentation $^{16,18-20}$. In a study by Perez et al., ${ }^{21}$ it was observed that only $35.9 \%$ of pregnant women in the first trimester had adequate serum 25(OH)D levels $(\geq 30 \mathrm{ng} / \mathrm{mL})$ and non-Caucasian ethnicity, season at sampling (autumn/winter) and nulliparity were found to be associated with $25(\mathrm{OH}) \mathrm{D}$ deficiency. The season at the time of serum sampling was also found to be important similar to previous studies which reported lower levels of vitamin $\mathrm{D}$ in the winter compared with summer season ${ }^{19,21}$.

A study measuring serum $25(\mathrm{OH}) \mathrm{D}$ levels of 79 pregnant women in the third trimester in our country found considerably a high rate of vitamin $\mathrm{D}$ deficiency in pregnant women during the winter season and it showed 
also the relationship between multivitamin supplementation, good socioeconomic status and high levels of vitamin $\mathrm{D}^{17}$.

We found no significant association between low $25(\mathrm{OH}) \mathrm{D}$ levels in the first trimester and adverse pregnancy outcomes which is in agreement with other reports ${ }^{9,13,22}$. Bodnar et al. $^{23}$ reported a five-fold increased risk of pre-eclampsia in women with $25(\mathrm{OH}) \mathrm{D}<15$ $\mathrm{ng} / \mathrm{mL}$ at $<22$ weeks of pregnancy. On the contrary, Shand et al. ${ }^{24}$ evaluated vitamin D status (between 10 and 20 week of gestation) in a group of women at high risk of pre-eclampsia and found no association between vitamin $\mathrm{D}$ deficiency and risk of pre-eclampsia. Wei et al. ${ }^{11}$ reported that $25(\mathrm{OH}) \mathrm{D}<20 \mathrm{ng} / \mathrm{mL}$ at late mid-trimester (24-26 weeks of gestation) but not early pregnancy (12-18 weeks of gestation) was associated with increased risk of pre-eclampsia. In contrast to our study, Parlea et al. ${ }^{25}$ noted a two- fold increased risk of GDM in women with $25(\mathrm{OH}) \mathrm{D}<29.4$ at $15-18$ weeks of gestation.

Similar to our findings, Thorp et al. ${ }^{26}$ reported no relation between recurrent preterm birth and low vitamin D levels $(<20 \mathrm{ng} / \mathrm{mL})$ in women at 16-22 week of gestation in a case control study of women with prior preterm birth. Although we found no correlation between the first trimester serum $25(\mathrm{OH}) \mathrm{D}$ levels and the neonatal gestational age or weight, a recent study demonstrated that first trimester $25(\mathrm{OH}) \mathrm{D}$ concentration of less than $12 \mathrm{ng} / \mathrm{mL}$ was associated with increased risk of low birth weight and SGA infants ${ }^{18}$. A study including 152 nulliparous women in Turkey showed that $44.6 \%$ of pregnant women have vitamin $\mathrm{D}$ deficiency and maternal vitamin $\mathrm{D}$ deficiency is associated with an increased risk of $\mathrm{SGA}^{27}$. The variation in results between studies may also be explained by differences in cut-off points used, population characteristics, sample size and methods to measure $25(\mathrm{OH}) \mathrm{D}^{22}$.

An interesting finding in our study was that women with higher levels of vitamin D at first trimester had higher rate of caesarean section than those with severe vitamin $\mathrm{D}$ deficiency. It might be explained by the fact that women who deliver vaginally were more likely to have risk factors for vitamin D deficiency such as wearing covered dress styles and less use of multi-vitamins than women who had caesarean section. Furthermore, the current study was focused primarily on the first trimester of pregnancy and we cannot rule out the possibility that differences in $25(\mathrm{OH}) \mathrm{D}$ concentrations become apparent only in the third trimester. A recent study with a large size of population revealed no association between the first trimester vitamin $\mathrm{D}$ status and the mode of delivery ${ }^{28}$. Our findings are in contrast to those of two other studies, Merewood et al. ${ }^{9}$ found almost four-fold increase in the rate of primary caesarean section in women with $25(\mathrm{OH}) \mathrm{D}$ levels below $15 \mathrm{ng} /$ $\mathrm{mL}$ at the time of the delivery, and Scholl et al. ${ }^{29}$ reported increased risk for caesarean delivery for women with 25(OH)D levels below $12 \mathrm{ng} / \mathrm{mL}$.

Strengths of the current study include its prospective design and the use of the gold-standard method for measuring $25(\mathrm{OH}) \mathrm{D}$ levels. The main limitation of this study, on the other hand, is the small sample size and the small number of women with adverse pregnancy outcome which limit making a definitive conclusion regarding the impact of vitamin D status on adverse pregnancy outcomes. In addition, we could not completely evaluate the underlying factors such as sunscreen use, skin pigmentation, socioeconomic status and lifestyle behaviour contributing to vitamin D status. The other limitation of our study is determining vitamin $\mathrm{D}$ status only in first trimester and the determination of vitamin $\mathrm{D}$ status in third trimester would be benefical to indicate the possible interaction of vitamin $\mathrm{D}$ in pregnancy outcomes. In spite of the limitations, this study adds to the few that report on serum $25(\mathrm{OH}) \mathrm{D}$ levels in the first trimester and its relation to pregnancy outcomes.

\section{Conclusion}

We propose that high prevalence of severe vitamin D deficiency in the first-trimester among pregnant women can be related with dress code, use of multi-vitamins and season at sampling. Low $25(\mathrm{OH}) \mathrm{D}$ levels may not be associated with increased risk of adverse pregnancy outcomes. Moreover, it is unanticipated that women with lower levels of vitamin D are more likely to deliver vaginally. Yet, further research is required to determine the levels of vitamin $\mathrm{D}$ in early pregnancy and the impact of low 25(OH)D concentrations on adverse pregnancy outcome.

\section{Declaration of interest}

The authors have no conflict of interest. 


\section{References}

1. Mithal A, Wahl DA, Bonjour JP, Burckhardt P, Dawson-Hughes B, Eisman JA, et al; IOF Committee of Scientific Advisors (CSA) Nutrition Working Group. Global vitamin D status and determinants of hypovitaminosis D. Osteoporos Int 2009; 20 (11): 1807 -1820.

2. van Schoor NM, Lips P. Worldwide vitamin D status. Best Pract Res Clin Endocrinol Metab 2011; 25 (4): 671-680. 3. Holick MF. Vitamin D deficiency. N Engl J Med 2007; 357 (3): 266-281.

4. Mulligan ML, Felton SK, Riek AE, Bernal-Mizrachi C. Implications of vitamin D deficiency in pregnancy and lactation. Am J Obstet Gynecol 2010; 202 (5): 429 -9. 5. ACOG Committee on Obstetric Practice. ACOG Committee Opinion No. 495: Vitamin D: Screening and supplementation during pregnancy. Obstet Gynecol 2011; 118 (1): 197-198.

6. Wang TJ, Zhang F, Richards JB, Kestenbaum B, van Meurs JB, Berry D, et al. Common genetic determinants of vitamin $\mathrm{D}$ insufficiency: a genome-wide association study. Lancet 2010; 376 (9736): 180-188.

7. Larcombe L, Mookherjee N, Slater J, Slivinski C, Singer M, Whaley C, et al. Vitamin D in a northern Canadian first nation population: dietary intake, serum concentrations and functional gene polymorphisms. PLoS One 2012; 7 (11): 49872.

8. Dror DK. Vitamin D status during pregnancy: maternal, fetal, and postnatal Outcomes. Curr Opin Obstet Gynecol 2011; 23 (6): 422-426.

9. Merewood A, Mehta SD, Chen TC, Bauchner H, Holick MF. Association between vitamin D deficiency and primary cesarean section. J Clin Endocrinol Metab 2009; 94 (3): 940-945.

10. Halicioglu O, Aksit S, Koc F, Akman SA, Albudak E, Yaprak I, et al. Vitamin D deficiency in pregnant women and their neonates in spring time in western Turkey. Paediatr Perinat Epidemiol 2012; 26 (1): 53-60.

11. Wei SQ, Audibert F, Hidiroglou N, Sarafin K, Julien $\mathrm{P}, \mathrm{Wu} \mathrm{Y}$, et al. Longitudinal vitamin $\mathrm{D}$ status in pregnancy and the risk of pre-eclampsia. BJOG 2012; 119 (7): $832-839$.

12. American Diabetes Association. Standards of medical care in diabetes--2009. Diabetes Care 2009; 32 Suppl 1: S13-61.

13. Fernández-Alonso AM, Dionis-Sánchez EC, Chedraui P, González-Salmerón MD,Pérez-López FR; Spanish Vitamin D and Women's Health Research Group. First-trimester maternal serum 25-hydroxyvitamin $\mathrm{D}_{3}$ status and pregnancy outcome. Int J Gynaecol Obstet 2012; 116 (1): 6-9.
14. Reddy UM, Ko CW, Willinger M. Maternal age and the risk of stillbirth throughout pregnancy in the United States. Am J Obstet Gynecol 2006; 195 (3): 764 -770.

15. Zhang J, Merialdi M, Platt LD, Kramer MS. Defining normal and abnormal fetal growth: promises and challenges. Am J Obstet Gynecol 2010; 202 (6): 522 -528. 16. Bener A, Al-Hamaq AO, Saleh NM. Association between vitamin $\mathrm{D}$ insufficiency and adverse pregnancy outcome: global comparisons. Int J Womens Health 2013; 5: 523-531.

17. Ustuner I, Keskin HL, Tas EE, Neselioglu S, Sengul O, Avsar AF. Maternal serum 25(OH)D levels in the third trimester of pregnancy during the winter season. $J$ Matern Fetal Neonatal Med 2011; 24 (12): 1421-1426.

18. Leffelaar ER, Vrijkotte TG, van Eijsden M. Maternal early pregnancy vitamin $\mathrm{D}$ status in relation to fetal and neonatal growth: results of the multi-ethnic Amsterdam Born Children and their Development cohort. Br J Nutr 2010; 104 (1): 108 -117.

19. Morley R, Carlin JB, Pasco JA, Wark JD. Maternal 25-hydroxyvitamin $\mathrm{D}$ and parathyroid hormone concentrations and offspring birth size. J Clin Endocrinol Metab 2006; 91 (3): 906-912.

20. Dawodu A, Akinbi H. Vitamin D nutrition in pregnancy: current opinion. Int J Womens Health 2013; 5: 333-343.

21. Pérez-López FR, Fernández-Alonso AM, Ferrando-Marco P, González-Salmerón MD, Dionis-Sánchez EC, Fiol-Ruiz G, et al. First trimester serum 25-hydroxyvitamin D status and factors related to lower levels in gravids living in the Spanish Mediterranean coast. Reprod Sci 2011; 18 (8): $730-736$.

22. Schneuer FJ, Roberts CL, Guilbert C, Simpson JM, Algert CS, Khambalia AZ, et al. Effects of maternal serum 25-hydroxyvitamin D concentrations in the first trimester on subsequent pregnancy outcomes in an Australian population. Am J Clin Nutr 2014; 99 (2): 287 $-295$.

23. Bodnar LM, Catov JM, Simhan HN, Holick MF, Powers RW, Roberts JM. Maternal vitamin D deficiency increases the risk of preeclampsia. J Clin Endocrinol Metab 2007; 92 (9): 3517-3522.

24. Shand AW, Nassar N, Von Dadelszen P, Innis SM, Green TJ. Maternal vitamin D status in pregnancy and adverse pregnancy outcomes in a group at high risk for pre-eclampsia. BJOG 2010; 117 (13): 1593 -1598.

25. Parlea L, Bromberg IL, Feig DS, Vieth R, Merman E, Lipscombe LL. Association between serum 25-hydroxyvitamin D in early pregnancy and risk of gestational diabetes mellitus. Diabet Med 2012; 29 (7): 25-32. 
26. Thorp JM, Camargo CA, McGee PL, Harper M, Klebanoff MA, Sorokin Y, et al; Eunice Kennedy Shriver National Institute of Child Health and Human Development Maternal-Fetal Medicine Units Network. Vitamin D status and recurrent preterm birth: a nested case-control study in high-risk women. BJOG 2012; 119 (13): 1617-1623.

27. Aydogmus S, Kelekci S, Aydogmus H, Eriş S, Desdicioğlu R, et al. High prevalence of vitamin D deficien- cy among pregnant women in a Turkish population and impact on perinatal outcomes. J Matern Fetal Neonatal Med 2015; 28 (15): 1828-1832.

28. Savvidou MD, Makgoba M, Castro PT, Akolekar R, Nicolaides KH. First-trimester maternal serum vitamin D and mode of delivery. Br J Nutr 2012; 108 (11): 1972 $-1975$.

29. Scholl TO, Chen X, Stein P. Maternal vitamin D status and delivery by cesarean. Nutrients 2012; 4 (4): $319-330$. 